The Chittagong Univ. J. B. Sci., Vol. 3(1 \&2): pp. 127-138, 2008.

\title{
NITROGEN TRANSFORMING ORGANISMS IN SOME FOREST SOILS OF CHITTAGONG UNIVERSITY CAMPUS
}

\author{
N. CHOWDHURY, M. S. ISLAM AND K. T. OSMAN* \\ Department of Soil Science, University of Chittagong, Chittagong 4331, Bangladesh
}

\begin{abstract}
Association of nitrogen transforming bacteria in soils under six-forest tree plantations viz. Lagerstroemia speciosa, Acacia auriculiformis, Acacia mangium, Dipterocarpus turbinatus, Tectona grandis, and Eucalyptus camaldulensis were assessed in the present study. Azotobacter population was the least among the nitrogen-transforming bacteria in all soils. Soils under $L$. speciosa had the lowest population of ammonifying, Nitrosomonas, Nitrobacter and denitrifying bacteria and $A$. auriculiformis had higher average MPN values, although E. camaldulensis had the highest Nitrobacter population. Population of the microorganisms was positively and significantly correlated with each other, except Azotobacter. Azotobacter was only significantly correlated with the denitrifying bacteria. The nitrogen-transforming microorganisms were significantly related with the total nitrogen content and $\mathrm{pH}$ of the forest soils.
\end{abstract}

Key words: Nitrogen transforming organisms, Forest soils, Tree Plantation.

\section{INTRODUCTION}

There are 1.43 million ha reserve forests and 0.73 million ha state forests corresponding to 10 and 6.7 percent respectively of the total land area in Bangladesh. The actual area under forest cover is much less, possibly less than 6 percent of the total land area (Hassan 1994). Efforts have been taken to combat the situation by afforestation and reforestation considering the economic and environmental aspects. Evergreen and mixed evergreen tropical rain forests once existed in the southeastern hills of Bangladesh. As the original dense natural cover has largely been removed, land and vegetation have been severely degraded. The Forest Department has planted several fast growing exotic tree species, such as acacias and eucalypts. There are plantations of some other indigenous fast growing species such as Albizia lebbeek, Albizia procera, Dalbergia sisso, etc., and slow growing species, such as Dipterocarpus turbinatus, Eugenia grandis, Hopea odorata, Chikrassia tabularis, etc.

\footnotetext{
${ }^{*}$ Corresponding Author :
} 
CHOWDHURY ET AL.

Forest vegetation mostly depends on the biological cycling of nutrients. Under natural undisturbed conditions, the nutrient cycling remains in an equilibrium with the ecosystem. When the forests are cleared or reforested by destroying the past vegetation, this balance is shifted and both soil fertility and tree nutrition are affected. Among all the nutrients, nitrogen is affected more because the sole source of nitrogen is the organic matter. For these reasons, transformation of nitrogen in forest soils has received much attention. Some workers (Zhang et al. 1988) have indicated that nitrogen transformation is related with the forest type and some others (Muller et al. 1980) showed that it could depend on forest management. There are some reports that the nitrogen supply to forest plants and nitrogen nutrition depend to a considerable extent on the ammonification and nitrification rates (Knowles 1981). Nitrogen fixation and denitrification are respectively two important processes of gain and loss of nitrogen in forest ecosystems (Muller et al. 1980).

Chittagong University is situated in the hilly area of Chittagong. The present work deals with study the soil properties of different forests of hilly areas of Chittagong University Campus and the association of nitrogen transforming soil bacteria with different tree species.

\section{MATERIALS AND METHODS}

\section{Site condition}

As there were appreciable variations within the same plantation area in either growth or soil or slope or all in some localities, due care was taken to identify the appropriate location. Conditions of the studied sites and associated tree species are shown in Table 1.

\section{Collection of soil samples}

Soil samples at $0-6 \mathrm{~cm}$ depths were collected with spade. To represent the site, several soil samples were collected from a particular depth in a sample plot. Then soils of a particular slope of a site were mixed in equal proportion to have a composite sample. The samples were taken in polythene bags and brought into laboratory. Each soil sample was divided into two sub-samples, one for the determination of physical and chemical properties and the other was used for the estimation of nitrogen-transforming microorganisms including Azotobacter, ammonifying bacteria, Nitrosomonas, Nitrobacter and denitrifying bacteria. 
NITROGEN TRANSFORMING ORGANISMS IN SOME FOREST SOILS

TABLE 1: CONDITIONS OF THE STUDY SITES OF DIFFERENT PLANTATIONS.

\begin{tabular}{ccll}
\hline $\begin{array}{c}\text { Site } \\
\text { No. }\end{array}$ & \multicolumn{1}{c}{ Species } & \multicolumn{1}{c}{$\begin{array}{c}\text { Study Area in Chittagong } \\
\text { University Campus }\end{array}$} & \multicolumn{1}{c}{ Site Characteristics } \\
\hline 1 & Acacia auriculiformis & East side of Godown & $\begin{array}{l}\text { Very steep slope, medium } \\
\text { hill }\end{array}$ \\
2 & Eucalyptus camaldulensis & Beside University play ground & Steep sloping, medium hill \\
3 & Lagerstroemia speciosa & Pump house & Steep sloping, medium hill \\
4 & Tectona grandis & East of Science Cafetoria & $\begin{array}{l}\text { Flat top of very steep slope, } \\
\text { high hill }\end{array}$ \\
5 & Acacia mangium & West side of Institute of & Gently sloping, low hill \\
& & Forestry and Environmental & \\
& & Sciences & \\
6 & Dipterocarpus turbinatus & South side of Shahjalal Hall & Steeply sloping, medium hill \\
\hline
\end{tabular}

Laboratory analysis

Soil samples were air dried and passed through a $2 \mathrm{~mm}$ sieve. Soil samples were kept in refrigerator for prior to microbial study.

Soil $\mathrm{pH}$ was determined in 1:2 soils (air dry): $0.01 \mathrm{M} \mathrm{CaCl}_{2}$ suspensions with an electronic digital pH meter (Jackson 1973). Particle size analysis was done according to Bouyoucos Hydrometer method (Day 1965) and the textural class names were those of USDA (1951). Soil organic carbon was determined by Walkley and Black's wet oxidation method (Jackson 1973). Cation exchange capacity was determined by $1 \mathrm{~N} \mathrm{NH}_{4} \mathrm{OAC}$ saturation followed by $10 \% \mathrm{KCl}$ displacement (Jackson 1973). Exchangeable $\mathrm{Na}^{+}, \mathrm{K}^{+}$were extracted with $1 \mathrm{~N}$ $\mathrm{NH}_{4} \mathrm{OAC}$ solutions ( $\mathrm{pH}$ 7.0). Available phosphorus was extracted from field moist soil samples by Bray and Kurtz No. 1 extractant $\left(0.03 \mathrm{~N} \mathrm{NH}_{4} \mathrm{~F}\right.$ in $0.025 \mathrm{~N}$ $\mathrm{HCl}$ ) and determined according to the $\mathrm{SnCl}_{2}$ reduced molybdophosphoric blue colour method (Jackson 1973). Potassium and sodium were determined by flame photometer.

\section{Estimation of microbial population}

Soil sample dilution

Ten gram of each soil sample was suspended in $95 \mathrm{ml}$ sterile distilled water in a conical flask, and mixed well with the help of a stirrer to get $10^{-1}$ dilution of the soil sample. Ten $\mathrm{ml}$ of this suspension was transferred to another conical flask containing $90 \mathrm{ml}$ sterile distilled water and mixed well with the help of a magnetic stirrer to get $10^{-2}$ dilution. In this way by gradual transfer and mixing $10^{-3}, 10^{-4}, 10^{-5}, 10^{-6}, 10^{-7}$ dilutions were prepared. 
CHOWDHURY ET AL.

\section{Estimation of Azotobacter}

Five tubes containing $10 \mathrm{ml}$ sterile solution (Mineral salt solution: $\mathrm{K}_{2} \mathrm{HPO}_{4}-5 \mathrm{~g}, \mathrm{MgSO}_{4} .7 \mathrm{H}_{2} \mathrm{O}-2 \mathrm{~g}, \mathrm{CaSO}_{4}-1 \mathrm{~g}, \mathrm{FeSO}_{4}-0.2 \mathrm{~g}, \mathrm{MnSO}_{4}-0.2 \mathrm{~g}, \mathrm{MoO}_{3}$. $\mathrm{H}_{2} \mathrm{O}-0.1 \mathrm{~g}$, KI-0.1g, Distilled water- $1000 \mathrm{ml}$. $10 \mathrm{~g}$ sucrose, $3 \mathrm{~g} \mathrm{CaCO}_{3}$ and $900 \mathrm{ml}$ of distilled water was added to $100 \mathrm{ml}$ of the mineral salt solution) were inoculated with $1 \mathrm{ml}$ of particular dilution. In this way the dilutions from $10^{-1}$ to $10^{-3}$ were used for the inoculation of tubes of solution. The inoculated tubes were incubated at $28^{\circ} \mathrm{C}$ for 1 week. Development of skin or pellicle on the surface of the culture fluid showed the positive result. Most Probable Number (MPN) of Azotobacter was calculated with the help of MPN chart from the number of positive tubes inoculated with higher dilutions (Rao 1986).

\section{Estimation of ammonifying bacteria}

Five tubes containing $7 \mathrm{ml}$ sterile nutrient broth solution (Peptone-5g, Beef extract-3g, NaCl- 1g, Distilled water-1000 ml) were inoculated with $1 \mathrm{ml}$ of particular dilution. In this way the dilutions from $10^{-4}$ to $10^{-7}$ were used for the inoculation of tubes of nutrient broth. The inoculated tubes were incubated at $30^{\circ} \mathrm{C}$ for 30 days. After incubation, 3 to 5 drops of Nessler's reagent (Solution-A: Potassium iodide-70g, Mercuric iodide-100g, Distilled water-500ml. Solution-B: Sodium hydroxide- $100 \mathrm{~g}$, Distilled water- $500 \mathrm{ml}$. Solution B was added into solution A in a $1000 \mathrm{ml}$ volumetric flask. Then it was shaken well and distilled water was added to make $1000 \mathrm{ml}$ ) was added to each tube. Development of brown colour showed the positive result. Most Probable Number of ammonifying bacteria was calculated with the help of MPN chart from the number of positive tubes inoculated with higher dilutions (Alexander 1965).

\section{Estimation of Nitrosomonas}

The population of Nitrosomonas was determined using ammoniumcalcium carbonate medium $\left\{\left(\mathrm{NH}_{4}\right)_{2} \mathrm{SO}_{4}-0.5 \mathrm{~g}, \mathrm{~K}_{2} \mathrm{HPO}_{4}-1.0 \mathrm{~g}, \mathrm{FeSO}_{4} .7 \mathrm{H}_{2} \mathrm{O}-0.03 \mathrm{~g}\right.$, $\mathrm{NaCl}-0.3 \mathrm{~g}, \mathrm{MgSO}_{4} .7 \mathrm{H}_{2} \mathrm{O}-0.3 \mathrm{~g}, \mathrm{CaCO}_{3}-7.5 \mathrm{~g}$, Distilled water - $1000 \mathrm{ml}$. Tubes of medium were inoculated with $1 \mathrm{ml}$ of each of soil dilutions from $10^{-3}$ to $10^{-7}$. Five tubes containing $3 \mathrm{ml}$ medium were inoculated with each dilution. The inoculated tubes were incubated at $28^{\circ} \mathrm{C}$ for 3 weeks. A set was included as uninoculated controls. After incubation, 3 to 5 drops of Griess-Ilosvay reagent was added to each tube. The presence of Nitrosomonas was indicated if the solution in inoculated tubes showed purplish-red colour. To all tubes that showed negative result, a small pinch of the $\mathrm{Zn}-\mathrm{Cu}-\mathrm{MnO}_{2}$ (1:1:1) mixture was added. Development of reddish colour showed the positive result for the presence of Nitrosomonas. Most Probable Number of Nitrosomonas was calculated with the help of MPN 


\section{NITROGEN TRANSFORMING ORGANISMS IN SOME FOREST SOILS}

chart from the number of positive tubes inoculated with higher dilutions (Alexander and Clark 1965).

\section{Estimation of Nitrobacter}

The population of Nitrobacter was determined by nitrite-calcium carbonate medium $\left(\mathrm{KNO}_{2}-0.006 \mathrm{~g}, \mathrm{~K}_{2} \mathrm{HPO}_{4}-1.0 \mathrm{~g}, \mathrm{FeSO}_{4} .7 \mathrm{H}_{2} \mathrm{O}-0.03 \mathrm{~g}, \mathrm{NaCl}-\right.$ $0.3 \mathrm{~g}, \mathrm{MgSO}_{4} .7 \mathrm{H}_{2} \mathrm{O}-0.1 \mathrm{~g}, \mathrm{CaCO}_{3}-1.0 \mathrm{~g}, \mathrm{CaCl}_{2}-0.3 \mathrm{~g}$, Distilled water $-1000 \mathrm{ml}$ ). Tubes of the medium were inoculated with $1 \mathrm{ml}$ of each of soil dilutions from $10^{-3}$ to $10^{-7}$. Five tubes containing $3 \mathrm{ml}$ medium were inoculated with each dilution. The inoculated tubes were incubated at $28^{\circ} \mathrm{C}$ for 3 weeks. After incubation, 3 drops of Griess-Ilosvay reagent was added to each tube. The presence of Nitrobacter was indicated if the solution in inoculated tubes remained colourless. Most Probable Number of Nitrobacter was calculated with the help of MPN chart from the number of positive tubes inoculated with higher dilutions (Alexander and Clark 1965).

\section{Estimation of denitrifying bacteria}

Each of 5 tubes containing $10 \mathrm{ml}$ liquid medium (Solution-A: $\mathrm{KNO}_{3}-1.0 \mathrm{~g}$, Asparagine-1.0g, Bromothymol blue (1\% in ethanol)-5.0 ml, Distilled water-500 ml. Solution-B: Na-Citrate-8.5g, $\mathrm{KH}_{2} \mathrm{PO}_{4}-1.0 \mathrm{~g}, \mathrm{MgSO}_{4} .7 \mathrm{H}_{2} \mathrm{O}-1.0 \mathrm{~g}, \mathrm{CaCl}_{2} .6 \mathrm{H}_{2} \mathrm{O}$ $-0.2 \mathrm{~g}, \mathrm{FeCl}_{3} .6 \mathrm{H}_{2} \mathrm{O}-0.05 \mathrm{~g}$, Distilled water- $500 \mathrm{ml}$. After preparation of solution $\mathrm{A}$ and $\mathrm{B}$, they were mixed and $\mathrm{pH}$ of the medium was adjusted within the range of 7.0 to 7.2) for denitrification test was inoculated with $1 \mathrm{ml}$ of each of soil dilutions from $10^{-3}$ to $10^{-7}$. The inoculated tubes were incubated at $30^{\circ} \mathrm{C}$ for 7 days. Vigorous gassing and blue colouration showed the positive result. Most Probable Number of denitrifying bacteria was calculated with the help of MPN chat from the number of positive tubes inoculated with higher dilutions (Alexander 1965).

\section{RESULTS AND DISCUSSION}

Populations of some nitrogen-transforming microorganisms-Azotobacter, ammonifying bacteria, Nitrosomonas, Nitrobacter and denitrifying bacteria in surface soils of different forest plantations under different slopes of Chittagong University Campus were estimated. Microbial populations, their variations with forest tree species and their relation with soil properties are discussed in the following sections.

\section{Population}

The average populations of Azotobacter, ammonifying bacteria, Nitrosomonas, Nitrobacter and denitrifying bacteria in soils under each tree 


\section{CHOWDHURY ET AL.}

species are summarized in the Table 2. Azotobacter population was the lowest among the nitrogen-transforming bacteria in any of the tree species and ranged from $2.2 \times 10^{3}$ to $74.1-\times 10^{3} / \mathrm{g}$ soil. The lowest population was found in soils under E. camaldulensis. Soils under D. turbinatus, $T$. grandis and $A$. auriculiformis had Azotobacter population more than twice the average value under E. camaldulensis. Populations of ammonifying bacteria, Nitrosomonas, Nitrobacter and denitrifying bacteria did not differ appreciably within the soil of a particular species. There were, however, some variations in soils among species.

TABLE 2: AVERAGE VALUES OF AZOTOBACTER, AMMONIFYING BACTERIA, NITROSOMONAS, NITROBACTER AND DENITRIFYING BACTERIA IN SOILS OF DIFFERENT FOREST TREE SPECIES OF CHITTAGONG UNIVERSITY CAMPUS.

\begin{tabular}{|c|c|c|c|c|c|c|}
\hline Microorganisms & Slope & $\begin{array}{c}\text { Azotobacter } \\
\text { (No. of total } \\
\text { MPN/g soil } \\
\times 10^{3} \text { ) }\end{array}$ & $\begin{array}{c}\text { Ammonifying } \\
\text { bacteria } \\
(\mathrm{MPN} / \mathrm{g} \text { soil } \\
\left.\mathrm{x} 10^{6}\right)\end{array}$ & $\begin{array}{c}\text { Nitrosomonas } \\
\text { (MPN/g soil } \\
\text { x10 })\end{array}$ & $\begin{array}{c}\text { Nitrobacter } \\
\text { (MPN/g soil } \\
\times 10^{6} \text { ) }\end{array}$ & $\begin{array}{c}\text { Denitrifying } \\
\text { bacteria } \\
(\mathrm{MPN} / \mathrm{g} \text { soil } \\
\left.\mathrm{x} 10^{6}\right)\end{array}$ \\
\hline \multirow{3}{*}{$\begin{array}{l}\text { Lagerstroemia } \\
\text { speciosa }\end{array}$} & Level & 11.6 & 0.67 & 0.79 & 0.77 & 0.71 \\
\hline & Medium & 49.5 & 0.89 & 1.01 & 0.93 & 0.88 \\
\hline & Top & 17.7 & 0.69 & 0.94 & 0.89 & 0.77 \\
\hline \multirow{3}{*}{$\begin{array}{l}\text { Acacia } \\
\text { auriculiformis }\end{array}$} & Level & 8.3 & 0.87 & 1.03 & 0.92 & 0.88 \\
\hline & Medium & 63.1 & 1.28 & 1.13 & 1.27 & 1.28 \\
\hline & Top & 22.8 & 1.21 & 1.25 & 1.25 & 1.13 \\
\hline \multirow{3}{*}{$\begin{array}{l}\text { Dipterocarpus } \\
\text { turbinatus }\end{array}$} & Level & 5.5 & 0.89 & 0.90 & 0.95 & 0.88 \\
\hline & Medium & 34.2 & 0.92 & 1.21 & 1.16 & 0.92 \\
\hline & Top & 15.0 & 0.89 & 0.99 & 1.02 & 0.91 \\
\hline \multirow{3}{*}{$\begin{array}{l}\text { Tectona } \\
\text { grandis }\end{array}$} & Level & 13.9 & 1.01 & 0.89 & 0.91 & 0.88 \\
\hline & Medium & 74.1 & 1.10 & 1.06 & 1.10 & 1.01 \\
\hline & Top & 25.3 & 0.91 & 1.05 & 1.09 & 0.94 \\
\hline \multirow{3}{*}{$\begin{array}{l}\text { Acacia } \\
\text { mangium }\end{array}$} & Level & 5.5 & 0.92 & 0.95 & 0.94 & 0.89 \\
\hline & Medium & 58.3 & 1.06 & 1.05 & 1.05 & 1.21 \\
\hline & Top & 8.4 & 0.96 & 0.95 & 1.00 & 1.06 \\
\hline \multirow{3}{*}{$\begin{array}{l}\text { Eucalyptus } \\
\text { camaldulensis }\end{array}$} & Level & 2.2 & 0.88 & 0.94 & 1.16 & 0.78 \\
\hline & Medium & 23.2 & 1.21 & 1.25 & 1.39 & 1.05 \\
\hline & Top & 15.4 & 1.21 & 1.32 & 1.43 & 1.05 \\
\hline
\end{tabular}

Thus, the ranges of MPN values of ammonifying bacteria, Nitrosomonas, Nitrobacter and denitrifying bacteria were $0.67 \times 10^{6}$ to $1.21 \times 10^{6}, 0.79 \times 10^{6}$ to 1. $32 \times 10^{6}, 0.77 \times 10^{6}$ to $1.43 \times 10^{6}$ and $0.71 \times 10^{6}$ to $1.28 \times 10^{6} / \mathrm{g}$ soil respectively. L. speciosa soils had generally lower populations of these organisms. On the other hand, A. auriculiformis had higher values average MPN, although E. camaldulensis had the highest Nitrobacter population. In all the forest 


\section{NITROGEN TRANSFORMING ORGANISMS IN SOME FOREST SOILS}

hills the numbers of microorganisms were found highest in mid hill as this layer was less disturbed due to steep slopes. The top hill and the hill base were anthropogenically disturbed as surrounding human population collect their fuel from the forests as leaves and twigs.

Soils under A. auriculiformis, E. camaldulensis and T. grandis plantations had no significant difference in population of ammonifying bacteria. Same was the case with $A$. mangium, and $T$. grandis; with A. mangium, D. turbinatus and with D. turbinatus, and L. speciosa. Both A. auriculiformis and E. camaldulensis differed significantly with A. mangium, D. turbinatus, and L. speciosa in population of Nitrosomonas. Its population in soils of A. auriculiformis, E. camaldulensis and $T$. grandis did not differ significantly with each other. On the other hand, there was no significant difference in population of Nitrosomonas under soils of A. mangium, D. turbinatus, L. speciosa and T. grandis. Nitrobacter population in soils of $E$. camaldulensis did not differ significantly with $A$. auriculiformis but differed significantly with all other species. There was no significant difference in soils of A. mangium, D. turbinatus and L. speciosa. Population of denitrifying bacteria in soils of $A$. auriculiformis differed significantly with all other species. On the other hand, denitrifying bacteria in soils of A. mangium, D. turbinatus, E. camaldulensis and T. grandis had no significant difference among themselves.

There are some reports on the population of nitrogen transforming bacteria in forest soils of different regions of the world. Ranjana and Nagaraj (1989) found that population of Azotobacter varied from $7 \times 10^{3}$ to $7 \times 10^{8} / \mathrm{g}$ in non-lateritic and dry deciduous forest soils. Zhang et al. (1988) found 14.41-x 10\% /g Azotobacter sp. and $8.73 \times 10^{5} / \mathrm{g}$ ammonifying bacteria in soils below Pinus massoniana. Chen et al. (1972) observed differences in population of nitrifying bacteria under pure Casuarina and mixed stands of Suhu coastal area of Taiwan. Lodhi and Ruess (1988) observed ammonifier and nitrifier populations and available $\mathrm{N}$ of associated soils in a forest community of red oak (Quercus rubra), hemlock (Tsuga canadensis), basswood (Tilia americana), sugar maple (Acer saccharum) and beech (Fagus grandifolia) near Ithaca, New York. Jones and Richards (1977) reported that nitrifying bacteria were more numerous in Pinus elliottii stands than in burned stands of Eucalyptus micrantha forest.

Interrelationships among microorganisms

The present study showed strong interrelationships among the soil microorganisms which may be apparent from the correlation coefficients 
calculated on the basis of the overall population in all the study sites (Table 3). Ammonifying bacteria was positively and significantly correlated with Nitrosomonas, Nitrobacter and denitrifying bacteria. In addition, Nitrosomonas was also correlated positively with ammonifying bacteria, Nitrobacter and denitrifying bacteria. Significant positive correlation at $0.01 \%$ level was again observed among ammonifying bacteria, Nitrosomonas, Nitrobacter and denitrifying bacteria. Azotobacter was only significantly related with denitrifying bacteria. Significant correlation between numbers of free-living cells of ammoniaand nitrite-oxidizing bacteria in a forest site was reported by Jha et al. (1996). Mai (1988) observed that Nitrosomonas and Nitrobacter in a forest soil were intercorrelated $(\mathrm{P}<0.001)$. The population of nitrifying bacteria is related to the supply of ammonia. Therefore, a relation between ammonifying bacteria and Nitrosomonas/Nitrobacter is evident.

TABLE 3: CORRELATION COEFFICIENTS AMONG MICROBIAL POPULATIONS IN SOILS

\begin{tabular}{llllll}
\hline & Azotobacter & $\begin{array}{l}\text { Ammonifying } \\
\text { Bacteria }\end{array}$ & Nitrosomonas & Nitrobacter & $\begin{array}{l}\text { Denitrifying } \\
\text { Bacteria }\end{array}$ \\
\hline Azotobacter & 1.000 & 0.442 & 0.316 & 0.233 & $0.574 *$ \\
$\begin{array}{l}\text { Ammonifying } \\
\text { Bacteria }\end{array}$ & 0.442 & 1.000 & $0.760 * *$ & $0.827 * *$ & $0.846^{* *}$ \\
Nitrosomonas & 0.316 & $0.760 * *$ & 1.000 & $0.892^{* *}$ & $0.627 * *$ \\
Nitrobacter & 0.233 & $0.892^{* *}$ & $0.892^{* *}$ & 1.000 & $0.630^{* *}$ \\
$\begin{array}{l}\text { Denitrifying } \\
\text { Bacteria }\end{array}$ & $0.574 *$ & $0.846^{* *}$ & $0.627 * *$ & $0.630^{* *}$ & 1.000 \\
\hline$*$ Significant at $0.05 \%$ level, **Significant at $0.01 \%$ level & &
\end{tabular}

*Significant at $0.05 \%$ level, **Significant at $0.01 \%$ level.

Relationship of microbial population with soil properties

The soils had appreciable differences in various physico-chemical and nutritional properties (Table 4). The overall effect of soil parameters on the population of the organisms is shown in Table 5. Soil pH was correlated positively and significantly with ammonifying bacteria, Nitrobacter and denitrifying bacteria at $0.01 \%$ level and with Nitrosomonas at $0.05 \%$ level. Ammonifying bacteria and Nitrosomonas were correlated with organic carbon at $0.05 \%$ level. All the nitrogen transforming bacteria are significantly and positively correlated with total nitrogen content of soils. Available phosphorus was positively correlated at $0.05 \%$ level only with Nitrosomonas bacteria. 


\section{NITROGEN TRANSFORMING ORGANISMS IN SOME FOREST SOILS}

TABLE 4: PHYSICO-CHEMICAL PROPERTIES OF SOILS IN SIX FOREST PLANTATIONS OF CHITTAGONG UNIVERSITY CAMPUS.

\begin{tabular}{|c|c|c|c|c|c|c|c|c|c|c|c|c|c|c|c|c|}
\hline Plantation & Location & $\begin{array}{l}\text { Site } \\
\text { Characteri } \\
\text { stics }\end{array}$ & Slope & Texture & $\mathrm{pH}$ & $\begin{array}{l}\mathrm{EC} \\
\mu \mathrm{s} / \mathrm{cm}\end{array}$ & $\begin{array}{l}\text { Org. C } \\
\%\end{array}$ & $\begin{array}{l}\text { Org. } \\
\text { matter } \\
\%\end{array}$ & $\begin{array}{l}\mathrm{C} / \mathrm{N} \\
\text { ratio }\end{array}$ & $\begin{array}{l}\text { CEC } \\
\mathrm{me} / \\
100 \mathrm{~g}\end{array}$ & BSP & $\begin{array}{l}\text { TEB } \\
\text { meq } \\
/ \\
100 \\
\mathrm{~g}\end{array}$ & $\begin{array}{l}\text { Total } \\
\mathbf{N} \\
\%\end{array}$ & $\begin{array}{l}\text { Availabl } \\
\text { e Pmg/ } \\
100 \mathrm{~g}\end{array}$ & $\begin{array}{l}\text { Total } \\
\text { K\% }\end{array}$ & $\begin{array}{l}\text { Total } \\
\mathrm{Na} \%\end{array}$ \\
\hline \multirow[t]{3}{*}{ Lagerstroemia speciosa } & \multirow{3}{*}{$\begin{array}{l}\text { Pump house } \\
\text { of } \\
\text { Chittagong } \\
\text { University }\end{array}$} & \multirow{3}{*}{$\begin{array}{l}\text { Steep } \\
\text { sloping, } \\
\text { medium } \\
\text { hill }\end{array}$} & Level & Clay loam & 5.6 & 0.82 & 0.77 & 1.32 & 11.00 & 3.90 & 33 & 1.29 & 0.07 & 0.25 & 0.05 & 0.07 \\
\hline & & & Medium & $\begin{array}{l}\text { Sandy clay } \\
\text { loam }\end{array}$ & 5.7 & 1.23 & 1.14 & 1.96 & 14.25 & 5.60 & 38 & 2.13 & 0.08 & 0.79 & 0.06 & 0.08 \\
\hline & & & Top & Silt loam & 5.6 & 1.23 & 1.10 & 1.89 & 15.71 & 4.58 & 36 & 1.63 & 0.07 & 0.75 & 0.09 & 0.09 \\
\hline \multirow{3}{*}{ Acacia auriculiformis } & \multirow{3}{*}{$\begin{array}{l}\text { East side of } \\
\text { Godown }\end{array}$} & \multirow{3}{*}{$\begin{array}{l}\text { Very } \\
\text { steep } \\
\text { slope, } \\
\text { medium } \\
\text { hill }\end{array}$} & Level & Silt loam & 5.6 & 1.26 & 0.97 & 1.67 & 12.13 & 5.15 & 41 & 2.11 & 0.08 & 1.70 & 0.07 & 0.04 \\
\hline & & & Medium & Clay loam & 5.7 & 1.27 & 1.07 & 1.84 & 9.73 & 6.25 & 43 & 2.69 & 0.11 & 1.80 & 0.06 & 0.02 \\
\hline & & & Top & $\begin{array}{l}\text { Sandy clay } \\
\text { loam }\end{array}$ & 5.7 & 1.27 & 1.16 & 1.99 & 9.67 & 5.45 & 41 & 2.13 & 0.12 & 1.80 & 0.09 & 0.03 \\
\hline \multirow[t]{3}{*}{ Dipterocarpus turbinatus } & \multirow{3}{*}{$\begin{array}{l}\text { South side } \\
\text { of Shahjalal } \\
\text { Hall }\end{array}$} & \multirow{3}{*}{$\begin{array}{l}\text { Steep } \\
\text { sloping, } \\
\text { medium } \\
\text { hill }\end{array}$} & Level & Clay loam & 5.6 & 0.49 & 0.82 & 1.41 & 10.25 & 5.50 & 36 & 1.98 & 0.08 & 1.67 & 0.03 & 0.08 \\
\hline & & & Medium & Sandy clay & 5.6 & 1.24 & 0.94 & 1.62 & 10.44 & 7.50 & 37 & 2.78 & 0.09 & 1.65 & 0.09 & 0.01 \\
\hline & & & Top & $\begin{array}{l}\text { Sandy clay } \\
\text { loam }\end{array}$ & 5.6 & 0.42 & 0.84 & 1.44 & 9.33 & 7.00 & 36 & 2.52 & 0.09 & 1.52 & 0.04 & 0.02 \\
\hline \multirow[t]{3}{*}{ Tectona grandis } & \multirow{3}{*}{$\begin{array}{l}\text { Science } \\
\text { Cafeteria } \\
\text { east }\end{array}$} & \multirow{3}{*}{$\begin{array}{l}\text { Flat top of } \\
\text { very steep } \\
\text { slope, } \\
\text { high hill } \\
\end{array}$} & Level & Silt loam & 5.6 & 1.25 & 1.09 & 1.87 & 13.63 & 5.50 & 36 & 1.98 & 0.08 & 0.32 & 0.32 & 0.03 \\
\hline & & & Medium & Clay & 5.7 & 1.70 & 1.32 & 2.27 & 13.20 & 5.50 & 38 & 1.86 & 0.10 & 1.95 & 0.23 & 0.02 \\
\hline & & & Top & Clay & 5.7 & 0.64 & 0.90 & 1.55 & 10.00 & 4.90 & 36 & 1.98 & 0.09 & 1.08 & 0.03 & 0.04 \\
\hline \multirow[t]{3}{*}{ Acacia mangium } & \multirow{3}{*}{$\begin{array}{l}\text { West side } \\
\text { of Institute } \\
\text { of Forestry } \\
\text { and } \\
\text { Environmen } \\
\text { tal Sciences }\end{array}$} & \multirow{3}{*}{$\begin{array}{l}\text { Gently } \\
\text { sloping, } \\
\text { low hill }\end{array}$} & Level & Clay loam & 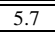 & 0.56 & 0.78 & 1.34 & 9.75 & 3.00 & 31 & 0.93 & 0.08 & 0.07 & 0.10 & 0.04 \\
\hline & & & Medium & Clay loam & 5.9 & 1.24 & 0.80 & 1.38 & 7.27 & 4.80 & 37 & 1.78 & 0.11 & 0.11 & 0.12 & 0.04 \\
\hline & & & Top & Loam & 5.8 & 1.26 & 0.96 & 1.65 & 9.6 & 2.95 & 34 & 0.66 & 0.10 & 0.08 & 0.12 & 0.04 \\
\hline \multirow[t]{3}{*}{ Eucalyptus camaldulensis } & \multirow{3}{*}{$\begin{array}{l}\text { Side of } \\
\text { university } \\
\text { play ground }\end{array}$} & \multirow{3}{*}{$\begin{array}{l}\text { Steep } \\
\text { sloping, } \\
\text { medium } \\
\text { hill }\end{array}$} & Level & Loam & 5.6 & 0.57 & 0.75 & 1.29 & 10.71 & 1.95 & 34 & 0.66 & 0.07 & 0.09 & 0.07 & 0.08 \\
\hline & & & Medium & Clay loam & 5.9 & 0.60 & 1.19 & 2.05 & 11.90 & 6.10 & 43 & 2.62 & 0.10 & 1.20 & 0.07 & 0.08 \\
\hline & & & Top & Clay loam & 5.9 & 0.60 & 1.19 & 2.05 & 11.09 & 6.10 & 42 & 2.62 & 0.10 & 1.30 & 0.09 & 0.08 \\
\hline & \multicolumn{3}{|l|}{ Range } & $\begin{array}{l}\text { Sandy Clay - } \\
\text { Clay }\end{array}$ & $\begin{array}{l}5.6- \\
5.9\end{array}$ & $\begin{array}{l}0.56- \\
1.26\end{array}$ & $\begin{array}{l}0.75- \\
1.19\end{array}$ & $\begin{array}{l}1.29- \\
2.05\end{array}$ & $\begin{array}{l}7.27- \\
11.90\end{array}$ & $\begin{array}{l}1.95- \\
6.10\end{array}$ & $31-43$ & $\begin{array}{l}0.66 \\
- \\
2.62 \\
\end{array}$ & $\begin{array}{l}0.07- \\
0.11\end{array}$ & $\begin{array}{l}0.07- \\
1.30\end{array}$ & $\begin{array}{l}0.07- \\
0.12\end{array}$ & $0.04-0.08$ \\
\hline \multicolumn{4}{|c|}{ Mean } & & 5.7 & 0.98 & 0.99 & 1.70 & 11.09 & 5.10 & 37.33 & 1.91 & 0.09 & 1.01 & 0.10 & 0.05 \\
\hline
\end{tabular}


CHOWDHURY ET AL.

TABLE 5: CORRELATION COEFFICIENTS BETWEEN MICROORGANISMS AND SOIL PROPERTIES

\begin{tabular}{lllll}
\hline Microorganisms & $\mathrm{pH}$ & $\begin{array}{l}\text { Organic } \\
\text { Carbon }\end{array}$ & $\begin{array}{l}\text { Total } \\
\text { Nitrogen }\end{array}$ & $\begin{array}{l}\text { Available } \\
\text { Phosphorus }\end{array}$ \\
\hline Azotobacter & 0.280 & 0.460 & $0.518^{*}$ & 0.334 \\
$\begin{array}{l}\text { Ammonifying } \\
\text { Bacteria }\end{array}$ & $0.655^{* *}$ & $0.550^{*}$ & $0.848^{* *}$ & 0.397 \\
$\begin{array}{l}\text { Nitrosomonas } \\
\text { Nitrobacter }\end{array}$ & $0.578^{*}$ & $0.560^{*}$ & $0.706^{* *}$ & $0.548^{*}$ \\
$\begin{array}{l}\text { Denitrifying } \\
\text { Bacteria }\end{array}$ & $0.610^{* *}$ & 0.445 & $0.660^{* *}$ & 0.410 \\
\hline
\end{tabular}

**significant at $0.01 \%$ level, *significant at $0.05 \%$ level

Investigations on the distribution of nitrogen transforming organisms with properties of soils have been done to a limited extent. Most workers indicated that there was a relationship of decomposable organic matter in soil with the population of heterotrophic nitrogen transformers (Hegazi et al. 1979).

Nitrification is much more sensitive to $\mathrm{pH}$ than is ammonification and at both low and high $\mathrm{pH}$ ammonium will tend to accumulate during soil incubations. The accumulation of ammonium will tend to be offset by the volatilization of ammonia with the increase of $\mathrm{pH}$ above 9. In pure culture nitrifiers grow well only between pH 6 and 8.5. However, there are some strains of Nitrobacter which are acidophilic (Hankinson and Schmidt, 1988). In addition, active nitrification has been reported in soils of pH 4-5 (Belser 1979).

The rate of denitrification was found to be different in different soils, depending on the $\mathrm{pH}$ of the soil, content of organic matter, structure, moisture, etc (Nommik 1956). The potential for denitrification in soil is positively correlated with pH (Muller et al. 1980), having an optimum between 7 and 8 (Van Cleemput and Patgrick 1974). Jansson and Clark (1952) observed that denitrification was considerably suppressed under acid conditions. Addition of organic material to soils has been shown to have a stimulating effect on denitrification (Nommik 1956). The organic material acts both as a carbon source and as a hydrogen donor for the denitrifying bacteria (Bailey 1976). Rates of denitrification are highly correlated with amounts of water-extractable soil organic carbon (Burford and Bremner 1975). 
NITROGEN TRANSFORMING ORGANISMS IN SOME FOREST SOILS

\section{CONCLUSION}

The hill soils distributed over the area within Chittagong University are poorly to moderately fertile. The cycling of nutrients and decomposition of forest litter is restricted due to removal of litter materials by the people of nearby areas. Organic matter and nitrogen content were relatively low. Population of nitrogen transforming microorganisms varied considerably and significantly with one another, with soil type and under different tree cover.

\section{REFERENCES}

ALEXANDER, M. 1965. Most Probable Number Method for Microbial Population. In: Methods of Soil Analysis. Ed. C. A. Black. Madison, Wisconsin. Am. Soc. Agros. 1467-1472.

ALEXANDER, M. AND CLARK, 1965. Nitrifying Bacteria. In: Methods of Soil Analysis. Ed. C. A. Black. Madison, Wisconsin. Am. Soc. Agros. 14771483.

BAILEY, L. D. 1976. Effects of temperature and root on denitrification in a soil. Can. J. Soil Sci. 56:79-87.

BELSER, L.W. 1979. Population ecology of nitrifying bacteria. Ann. Rev. Microbiol. 33: 309-333.

BURFORD, J. R. AND BREMNER, J. M. 1975. Relationships between denitrification capacities of soils and total water-soluble and readily decomposable soil organic matter. Soil Biol. and Biochem.7: 389-394.

CHEN, R. L., KEENEY, D. R.AND KONRAD, J. G. 1972. J. Environ. Qual. 1: 151-154.

DAY, P. R. 1965. Particle fractionation and particle-size analysis. In: C. A. Black (ed.). Methods of Soil Analysis, Part 1. Agronomy Monograph 9, ASA and SSSA, Madison, WI, pp. 545-567.

HASSAN, M. M., 1994. Forest soils of Bangladesh. Bangladesh J. For. Sci., 23(2): 1-11.

HANKINSON, T. R. AND SCHMIDT E. L. 1984. Examination of an acid forest soil for ammonia and nitrite-oxidizing autotrophic bacteria. Can. J. Microbiol. 30:1125-1132.

HEGAZI, N. A. EDI, M., FRAG, R. S. AND MONIB, M. 1979. Asymbiotic nitrogen fixation in the rhizosphere of sugarcane planted under semiarid condition of Egypt. Rev. Ecol. Biol. Sci. 16(1): 23-37.

JACKSON, M. L. 1973. Soil Chemical Analysis. Prentic Hall of India Pvt. Ltd., New Delhi, pp. 1-498. 
JANSSON, S. L. AND CLARK, F. E. 1952. Losses of nitrogen during decomposition of plant material in the presence of inorganic nitrogen. Soil. Sci. Soc. Amer. Proc. 16: 330-334.

JHA, P. B, SINGH, J. S. AND KASHYAP, A. K. 1996. Dynamics of viable nitrifier community and nutrient availability in dry tropical forest habitat as affected by cultivation and soil texture. Plant and Soil. 180: 277-285.

JONES, J. M. AND RICHARDS, B. N. 1977. Changes in the microbiology of eucalypt forest soils following reforestations with exotic pines. Aust. For. Res. 7: 229-240.

KNOWLES, R. 1981. Denitrification. In: Soil Biochemistry. 5. Eds. E. A. Paul and J. Ladd, Marcel Dekker, Inc., New York, pp. 37-95.

LODHI, M. A. K. AND RUESS, R. W. 1988. Variations in soil nitrifiers and leaf nitrate reductase activity of selected tree species in a forest community. Soil Biol. and Biochem. 20: 939-943.

MAI, H. 1988. Nitrification in raw humus under Norway spruce stands. Zentralblatt fur Mikrobiologie. 143: 229-237.

MULLER, M. M., SUNDMAN, V AND SKUJINS, J. 1980. Denitrification in low $\mathrm{pH}$ spodosols and peats determined with the acetylene inhibition method. Appl. Environ. Microbiol. 40: 235-239.

NOMMIK, H.1956. Investigations on denitrification in soil. Acta Agric. Scandinavica. 6: 195-228.

RANJANA, N. AND NAGARAJ, R. 1989. Occurrence of Azotobacter and Beijerinckia in forest soils of Maharashtra. Indian J. For. 12(2): 112116.

RAO, N. S. S. 1986. Soil Microbiology (4 ${ }^{\text {th }}$ ed.). Oxford and IBH Publishing Co. Pvt.Ltd., New Delhi, pp. 295-297.

USDA, 2004. Soil Survey Manual, United States Department of Agriculture, Handbook No. 18, New Revised Edition, Scientific Publishers, Jodhpur, India, 437p.

VAN CLEEMPUT, D. AND PATGRICK, W. H. 1974. Nitrate reduction in flooded gamma-irradiated soil under controlled $\mathrm{pH}$ and redox potential conditions. Soil Biol. and Biochem. 6: 85-88.

ZHANG, D. H., YANG, Y. S., WU, Z.X. AND LI, Z.W. 1988. A preliminary study of the microflora in soils and soil fertility in the stands of Pinus massoniana mixed with Schima superba. For. Sci. and Tech. 9: 6-8.

Manuscript received on 21.10.08; Accepted on 7.1. 09

The Chittagong University Journal of Biological Sciences, Vol. 3( 1 \& 2): pp.127-138, 2008. 